\title{
DANUBE WATER LEVELS - FRACTAL ANALYSIS
}

DOI: http://dx.doi.org/10.18509/GBP.2019.74

UDC: 528.931.067:556.53(498)

\author{
Andronache Ion ${ }^{1}$ \\ Popa Mihnea Cristian ${ }^{1,2}$ \\ Diaconu Daniel Constantin ${ }^{1}$ \\ ${ }^{1}$ Centre for Integrated Analysis and Territorial Management, \\ University of Bucharest, Faculty of Geography, Romania \\ 2 Doctoral School "Simion Mehedinţi - Nature and Sustainable Development" \\ University of Bucharest, Faculty of Geography, Romania
}

\begin{abstract}
Analysis of the hydrological regime of the rivers can provide a number of important information in the management activity and basin planning. At the same time, the impact of global climate change, land use as well as hydro technical and hydro power can be determined by fractal analysis of the hydrological values. In this regard, the present paper aims to test the Ruler Dimension, a fractal analysis method, to quantify the complexity of the dynamics of the Danube River water level, at the Braila hydrometric station. The fractal analysis was also used for the analysis of groundwater levels in the Balta Mare area of Braila, on the Gropeni Peceneaga alignment. Daily average values of the level were used in the analysis, over a time interval between 1997-2011. There was a close connection between the dynamics of the Danube levels and those of the groundwater, revealing a delay that gradually increases towards the interior of the Balta Mare of Brăila.
\end{abstract}

Keywords: hydrological time series, fractal analysis, Danube

\section{INTRODUCTION}

Groundwater distribution and dynamic fluctuations in underground water and surface water levels have a direct impact on the quality of the environment as well as on human activities [1]. Aquifer level fluctuations are the dynamic responses of the system to recharging and discharging it by surface water sources (rivers, lakes, precipitations) [2]. The present study refers to the analysis of groundwater and surface water evolution on a smaller scale, both spatial and temporal. The study is based on the application of the Ruler Dimension fractal analysis method to quantify the complexity of the dynamics of the Danube River water level at the Braila hydrometric station and the response from the underground water. Fractal analysis is a relatively recent tool for analysis of data series or images. In this study we started analyzing data strings, in particular Danube levels and piezometric levels in Braila Balta Mare. There are more possibilities to analyze fractal data strings directly (such as Higuchi dimension, Hurst Analysis) or plotting followed by fractal analysis of resulting curves (such as Ruler Dimension, Box-Counting) [3]. Most studies are based on classical approaches, on direct quantitative correlations between parameters, on medium and large time series. The fractal analysis method was also tested on the morphometric parameters of the river network to obtain encouraging results [4], [5]. The chosen approach will allow for a rapid and accurate analysis of variations in hydrological parameters and the interdependence between them. 


\section{MATERIALS AND METHODS}

\section{Study area}

Balta Brailei was formed in the last 10,000 years, after the end of the quaternary era, by the deflection of a former Marine Gulf (Halmyris) with alluviums by the Danube. At the beginning of the Holocene, as a result of the melting of the glaciers, the Black Sea level increases, which leads to the alluvialisation and the carving of the terraces. The lowest absolute altitudes are represented by the bottom of Zaton Lake and the Old Danube (Macin's branch). The highest altitude, 45 meters, we meet in the Blasova poplin, the rest of the Dobrogea Mountains sinked and eroded over time.

From the lithological point of view, alluvial deposits of 40-60 meters thickness could be divided into two complexes: one of the surfaces, clay-lute-malos of 4 to 10 meters thick and one deep, represented from the top down by fine sands, coarse sands with gravel and boulders with a thickness of 25-30 meters. Surface deposits have a cross-stratigraphic structure, intercalating, clay deposits with clay and clay sands, some with organic content and high plasticity. These materials constitute the rock on which the soils form, predominantly the ones with fine texture, while the granulometry of the alluvial deposits grows with the depth, semi-permeable deposits up to about 90 meters deep, fine sands up to 25-30 meters, coarse sands and gravels at about 100 meters. Holocene-inferior deposits are represented by the slopes of the lower Danube river terrace and the loessoid deposits of the Danube Meadow. The accumulations of the Danube's low terrace are made up of sandy and slightly clayey sands, 4 to 10 meters thick. Loess deposits are of a sandy character, they are macroporous of yellowish color. In the north of Brăilei Balta (Brăila wetland), they become more and more sandy. Their thickness is 4 to 10 meters. The loessoid deposits of the lower terrace, alluvial accumulations of the meadows and wind sands in the region were attributed to the superior Holocene.

Climate is temperate continental with a multi-annual average temperature of $+10.0^{\circ} \mathrm{C}$. The air temperature recorded absolute maximum and minimum values: $40.5^{\circ} \mathrm{C}$ and 26.5

${ }^{\circ} \mathrm{C}$ respectively. Precipitation is low, below $400 \mathrm{~mm} / \mathrm{year}$. Most precipitations, about 60\%, fall between April 1 and September 30, when plants need more moisture, and the fewest in October-March. Snow covers the earth intermittently, about 30 days / year.

\section{Data sampling}

Daily data of Danube levels at the water level meters Brăila from 1 January 1997 to 31 December 2011 were analyzed. These were correlated with the 3 to 3-day recordings of 6-hole groundwater levels from the Gropeni-Peceneaga alignment. 3 of the boreholes were near the Măcin branch (F1-F3) and 3 located near the Navigable Danube (F4-F6). The drilling alignment intersects the Măicanu and Bălaia drainage systems. Sinetic data about the 6 drillings are shown in Table 1 .

The activity of monitoring the hydrological regime of the lower course of the Danube has a history of more than 150 years. The first measuring station was established in Orșova in 1836, followed by Drencova in 1854 and Baziaș in 1874, both located in the Iron Gate defile and also in Brăila, Galati, Tulcea in 1874. Over the years, the number of stations the measurement has increased, currently reaching 21 stations with observations on level variations and 20 stations with measurements of fluid discharge [6].

Daily data of Danube levels at the hydrometer Brăila from 1 January 1997 to 31 December 2011 were analyzed. These were correlated with the 3 to 3-day recordings of 6-hole groundwater levels from the Gropeni-Peceneaga alignment. 3 of the boreholes were near 
the Măcin branch (F1-F3) and 3 located near the Navigable Danube (F4-F6). The drilling alignment intersects the Măicanu and Bălaia drainage systems. Sinetic data about the 6 drillings are shown in Table 1.

Table 1. Characteristics of drilling F1-F6

\begin{tabular}{|c|c|c|c|c|c|}
\hline No. & Drilling & Distance towards the bank & $\begin{array}{c}\text { Elevation } \\
(\mathbf{m})\end{array}$ & Localization & $\begin{array}{c}\text { Medium } \\
\text { levels (cm) }\end{array}$ \\
\hline $\mathbf{1}$ & F1 & $365 \mathrm{~m}$ towards the left bank (Macin branch) & 6,77 & High area & 255 \\
\hline $\mathbf{2}$ & F2 & $1.525 \mathrm{~m}$ towards the left bank (Măcin branch) & 6,5 & High area & 245 \\
\hline $\mathbf{3}$ & F3 & $5.940 \mathrm{~m}$ towards the left bank (Măcin branch) & 5,7 & Low area & 171 \\
\hline $\mathbf{4}$ & F4 & $5.510 \mathrm{~m}$ towards the right bank (Dunabe) & 5,1 & Low area & 201 \\
\hline $\mathbf{5}$ & F5 & $3.010 \mathrm{~m}$ towards the right bank (Dunabe) & 5,3 & Low area & 169 \\
\hline $\mathbf{6}$ & F6 & $120 \mathrm{~m}$ towards the right bank (Dunabe) & 7,4 & High area & 214 \\
\hline
\end{tabular}

It is noticed that 3 of them are in the low and three are in the high area and the levels drop from the Danube towards the interior of Braila's Balta Mare enclosure.

\section{Plotting levels}

For the level dynamics analysis at the Braila hydrometric station, at the daily data level of the year, for the period 1997-2011, 15 plots were made. These were done using Microsoft Excel 2007. The same methodology was applied to the plot of the 12-month average values for the Danube levels, but also for the groundwater levels in Braila's Balta Mare. The resulting images were exported to ImageJ, binarized and converted to bmp for fractal analysis. Those images had a $1461 * 897$-pixel resolution.

\section{Ruler Dimension Determination}

Ruler Dimension is a method using for estimating the fractal dimension of a jagged, selfsimilar line, the typical example being a coastline.

Define $N(d)$ as the number of steps taken by walking a ruler (divider) of length $d$ on the line, the ruler dimension $D_{r}$ is defined as (Eq. 1):

$$
N(d) \approx d^{-D_{r}}
$$

If the line is Euclidean, $D_{r}=1$, then the length of the line will be a constant independent of $d$. This is bound to be true for values of $d$ sufficiently small. At the other extreme, if the line completely fills space, $D_{r}=2$, i.e., the length of the line is linearly related to the length of the ruler.

The more the data is more complex, and the resulting plotting is more jagged, the value of the Ruler Dimension tends towards 2. When the oscillations are minimal, the resulting plots tend to linearly and tends to be towards 1 . If the line is indeed fractal, this plot will follow a straight line with a negative slope that equals $-D_{r}$.

The Ruler dimension is a method of determining the fractal dimension specific to a serrated line similar to a coastal line [7]. In the Dimension Ruler analysis, first, $N$ (d) is defined as the number of steps taken by displacing a divisor (ruler) d, on the line, Thus, the ruler dimension $D_{\mathrm{r}}$ is defined as $\mathrm{N}(\mathrm{d}) \approx \mathrm{d}^{-\mathrm{D}_{\mathrm{r}}}(1)$

If the line is Euclidean, $D_{r}=1$, then the length of the line will be a constant independent of $d$. This is also true for $d$ values sufficiently small. On the opposite pole, if the line fills the space completely, $D_{r}=2$, i.e. the length of the line is linearly linked to the length of 
the ruler. When $D_{r}=2$, the number of filled boxes is proportional to $\frac{1}{d^{2}}$, and the line completely fills the two-dimensional space.

The more detailed the analyzed data is, the more complex the plot results, the Ruler Dimension gets closer to 2 , and vice versa when the oscillations are minimal, the resulting plot lines are linear. The magnitude of the variation tends to 1 . If the line is indeed fractal, this plot will follow a straight line with a negative slope that equals $-D_{r}$.

\section{RESULTS}

\section{Danube levels}

The anthropic intervention has exerted an important action on the conditions of stability of the whites due to both the depths of the water in the floods and the decrease of the solid flow. The hydrological regime of the Danube is particularly complex due to the different sources of supply for the over 120 of the tributaries and the climatic differences from which they come from. At present, the Danube waters are growing in a relatively short time relative to the increases that the river has recorded before the embankments, and then the setting up of the Iron Gates 1 and 2 hydropower system and the Danube-Black Sea channel, the overflows focusing on three periods [8]:

- February-March, when the snow in the pools of Savei, Dravei and Moravei melts and the snow starts melting in the rest of the Danube basin;

- April-June, when the maximum shares of the river are achieved;

- November-December, when there is usually a slight increase in water levels, but in autumns with high rainfall there may be large floods, which in $95 \%$ are calamity due to ice bridges generated by low temperatures [9].

The dredging of the Danube course led to the decrease of the drainage section, which imposed a higher level compared to the previous situation. Following dump, at the same recorded flow the levels are higher. For example: at $6300 \mathrm{~m}^{3} / \mathrm{s}$. registered in Brăila, the level increased after $39 \mathrm{~cm}$ (from $286 \mathrm{~cm}$ to $325 \mathrm{~cm}$ ); at a flow rate of $11900 \mathrm{~m}^{3} / \mathrm{s}$, recorded in Brăila, the level increased by $26 \mathrm{~cm}$ (from $547 \mathrm{~cm}$ to $573 \mathrm{~cm}$ ); at the flow rate of $2030 \mathrm{~m}^{3} / \mathrm{s}$, recorded in Brăila, the level increased by $32 \mathrm{~cm}$ (from $15 \mathrm{~cm}$ to $47 \mathrm{~cm}$ ).

Following the complex land improvement works, the hydrological regime of the Danube continues to exert a strong influence on the hydrogeological regime of Brăila Băilei. Because the level of the Danube is above the average level of the groundwater, the supply is phreatic [10].

\section{Fractal analysis of the dynamics of the daily Danube levels}

In figure 1 it is noticeable that in the years with high floods 2006, 2010, the dynamics of the levels was less complex, with the Ruler Dimension being 1.24 and 1.28, respectively. The years 2001, 2004 and 2007 had a greater complexity of Ruler Dimension values above 1.34 we mention that all these 3 years had average values of the Danube levels below the average of the analyzed period. 


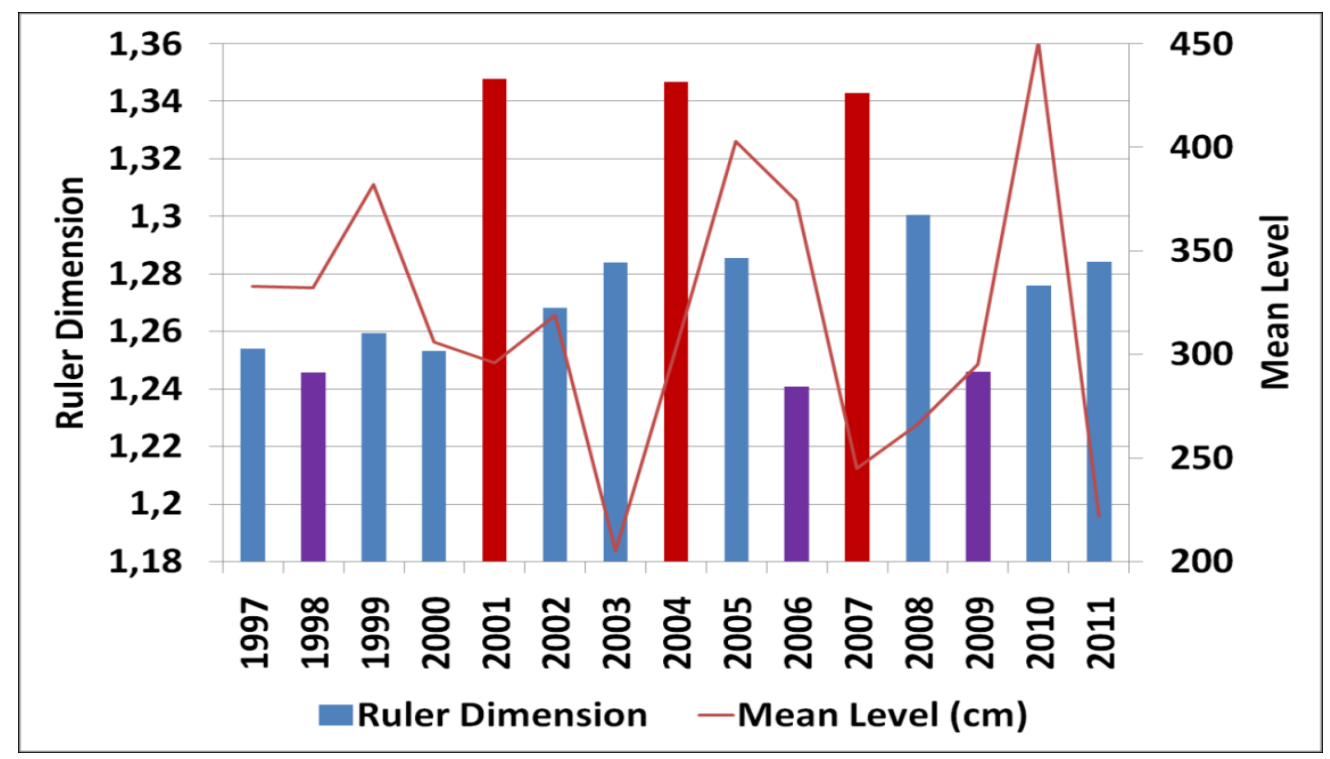

Figure 1. Ruler Dimension Values depending on the mean level, Brăila, Danube.

Also, from the Ruler Dimension analysis of the dynamics of the daily Danube levels, one can distinguish a possible cyclicity of maximum complexity given at 3-4 years.

The correlation between the Danube (Brăila) and the groundwater (Balta Mare of Brăila) for the monthly multiannual average values

The effect on the Danube river basin is related to the magnitude of the flood, its duration and the effect of precipitations falling in future periods. The influence of the Danube on the groundwater is more pronounced from upstream and from the center to the periphery depending on the alluvial deposits texture and the river's distance.

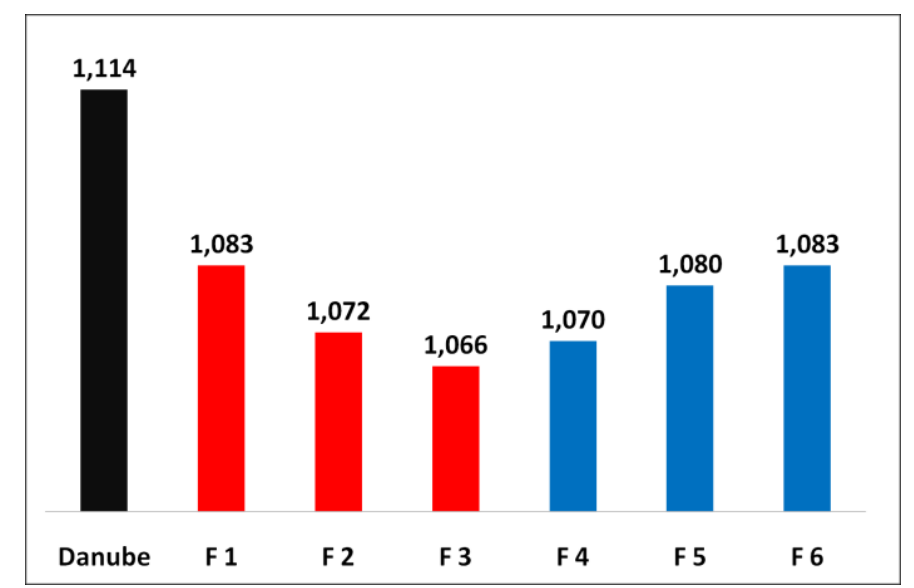

Figure 2. The relation between Danube water level and adjacent groundwater level, Brăila

The highest level $(<1 \mathrm{~m})$ is recorded in April-May and is located on the outskirts, mostly upstream, with a width and can reach a kilometer. Highest levels are recorded in OctoberNovember, especially in the central sector and more extensive in the downstream half.

The effect of the Danube on the hydrogeological regime is more important when its level exceeds the $500 \mathrm{~cm}$ share at Mira Brăila). At the high levels of the Danube, groundwater reaches the depression area at 0,4-0,8 $\mathrm{m}$ and in the area of the ridges at 1,2-1,8 $\mathrm{m}$. At the low levels of the Danube, in the depression areas, the depth of the groundwater becomes 1,5-3 m. 
Immediately after the introduction of the irrigation, an increase in the groundwater level was recorded with $58 \mathrm{~cm}$ in the Filipoiu sector, $40 \mathrm{~cm}$ in the Măicanu and Bălaia sectors. The main causes were the application of large watering rules on the one hand and the high permeability of soils on the other. To this was added the loss of water on the badly lined channels [10]. Thus, areas with groundwater at depths less than $2 \mathrm{~m}$ increased after the introduction of irrigations from $15 \%$ to $52 \%$ after the introduction of irrigation, while the area with groundwaters over $3 \mathrm{~m}$ decreased from $31 \%$ to $16 \%$.

The fractal analysis of figure 2 shows the correlation between the Danube and the Danube levels. As we depart from the two arms of the Danube, from F1 to F3 and from F6 to F4, the phreatic level shows a decrease in the complexity of their dynamics. This highlights the decrease of the Danube's influence on the evolution of the groundwater dynamics (a mitigation of the phreatic levels). This was possible due to the dikes building and the transformation of the Great wetland of Brăila into the agricultural area of the Great Island of Brăila, but also to the irrigation input to eliminate the water deficit installed in the enclosure after a dike has been built.

\section{CONCLUSIONS}

Fractal dimension is useful in analyzing time series, providing information about the complexity of data dynamics.

The Ruler Dimension analysis has shown the possibility of identifying cyclical dynamics of annual Danube levels. It also allowed to identify new relations between the Danube and the Danube, after indigestion. Thus, as the river deflection decreases, the dynamics of its levels decrease, reflecting the decrease in the complexity of the groundwater dynamics.

The methodology used provides a consistent plus of the established approaches to understanding the complexity of spatial distribution phenomena. The study also shows the need to use fractal analysis along with statistical analyzes or GIS modeling, commonly found in specialty literature [11], [12], [13], [14], [15], [16].

\section{REFERENCES}

[1] Diaconu D.C., Bretcan P., Peptenatu P., Tanislav D., Mailat E. The importance of the number of points, transect location and interpolation techniques in the analysis of bathymetric measurements. Journal of Hydrology, Volume 570, 2019, Pages 774-785.

[2] Gâştescu P., Țuchiu E., The Danube river in the lower sector in two hydrological hypostases - High and Low waters, Riscuri și Catastrofe XI, Vol. 10, 2012, pp. 165-182.

[3] Andronache I., Ahammer H., Jelinek H. F., Peptenatu D., Ciobotaru A. M., Drăghici C. C., Pintilii R. D., Simion A. G. \& Teodorescu C. Fractal analysis for studying the evolution of forests, Chaos Solitons \& Fractals, vol. 91, 2016, pp 310-318.

[4] Diaconu, D.C., Andronache, I., Ahammer, H., Ciobotaru, A.M., Zelenakova, M., Dinescu, R., Pozdnyakov, A.V., Chupikova, S.A. Fractal drainage model - a new approach to determinate the complexity of watershed, Acta Montanistica Slovaca, Volume: 22, Issue: 1, 2017, Pages: 12-21.

[5] Eltarabily, M.G., Negm, A.M., Yoshimura, C., Takemura, J. Groundwater Modeling in Agricultural Watershed under Different Recharge and Discharge Scenarios for Quaternary Aquifer Eastern Nile Delta, Egypt. Environmental Modeling \& Assessment, Volume: 23, Issue: 3, 2018, Pages: 289-308.

[6] ***(2010), Analiza regimului hidrologic al fluviului Dunării pe teritoriul României, South East Europe, Danube Floodrisk. 
[7] Benoit M., How Long Is the Coast of Britain? Statistical Self-Similarity and Fractional Dimension, Science, Vol. 156, Issue 3775, 1967, pp. 636-638,

[8] Popescu, I., R., Popescu, I., V., Neculescu, H., Anghel, D., 1982: Metode diferențiate de aplicare a tratamentului tăierilor în scaun la arborete de salcie din lunca inundabilă a Dunării în funcție de hidrograd. Brevet avizat de I.C.A.S., nr. 45/1984.

[9] Moisei, R. Zavoiul Begu, model pentru reconstructia ecologica in Parcul Natural Balta Mica a Brailei, Revista pădurilor, nr. 4, 2006.

[10] Visinescu I. Contributii la estimarea bilantului hidrologic al incintei Insula Mare a Brailei, Teza de doctorat, IANB, Bucuresti, 1979.

[11] Peptenatu D., Merciu C., Merciu G., Drăghici C., Cercleux L. Specific features of environment risk management in emerging territorial structures, Carpathian Journal of Earth and Environmental Sciences, vol. 7, 2012, pp 135-143.

[12] Pintilii R. D., Andronache I., Simion A. G., Drăghici C. C., Peptenatu D., Ciobotaru A. M., Dobrea R. C., Papuc R. M. Determining forest fund evolution by fractal analysis (SuceavaRomania), Urbanism Architecture Constructions, vol. 7, 2016, pp 31-42.

[13] Drăghici C. C., Peptenatu D., Simion A. G., Pintilii R. D., Diaconu D. C., Teodorescu C., Papuc R. M., Grigore A. M., Dobrea C. R. Assessing economic pressure on the forest fund of Maramures County - Romania, Journal of Forest Science (Prague), vol. 62, 2016, pp 175-185.

[14] Drăghici C. C., Andronache I., Ahammer H., Peptenatu D., Pintilii R. D., Ciobotaru A. M., Simion A. G., Dobrea R. C., Diaconu D. C., Vișan M. C., Papuc R. M. Spatial evolution of forest areas in the northern Carpathian Mountains of Romania, Acta Montanistica Slovaca, vol. 22, 2017, pp 95-106.

[15] Prăvălie R., Patriche C. V., Sîrodoev I., Bandoc G., Dumitraşcu M., Peptenatu D. Water deficit and corn productivity during the post-socialist period. Case study: Southern Oltenia drylands, Romania, Arid Land Research and Management, vol. 30, 2016, pp 239-257.

[16] Pintilii R. D., Andronache I., Diaconu D. C., Dobrea R. C.., Zelenakova M., Fensholt R., Peptenatu D., Draghici C. C., Ciobotaru A. M. Using Fractal Analysis in Modeling the Dynamics of Forest Areas and Economic Impact Assessment: Maramures County, Romania, as a Case Study, Forests, vol. 8, 2017. 